\title{
Evidence-Based Practices for the Prevention of Pressure Ulcers
}

\author{
Basınç Yaralarının Önlenmesinde Kanıt Temelli Uygulamalar
}

Aylin AYDIN SAYILAN ${ }^{1}$

öz

Basınç (dekübit) yaraları, cilt üzerinde uzun süreli basınçtan kaynaklanan, bireyin yaşam kalitesini olumsuz etkileyen, cilt ve altındaki dokuda meydana gelen yaralanmalardır. Yaralar, en sık vücuttaki kemik bölgelerini kaplayan cilt üzerinde gelişir. Basınç yaralarının gelişiminde risk faktörleri olarak; hareketsizlik, duyusal algısal eksiklik, yetersiz beslenme, yetersiz hidrasyon, kan akışını bozan tıbbi durumlar olarak belirtilmekte, erken tanılanmasının önemi vurgulanmaktadır.

Basınç yaralarına yönelik hemşirelerin, cilt bakımı, beslenme, pozisyon değişimi, eğitim ve kanıt temelli bir bakım sürdürme konusunda duyarlı olmaları gerekir. Bu derleme, basınç yaralarının nedenleri, ilişkin risk faktörleri ve basınç yaralarının önlenmesi hakkında bilgiler içermektedir.

Anahtar Kelimeler: Önlem, basınç, ülser
Aylin AYDIN SAYILAN (两)

${ }^{1}$ Kirklareli University Health School Nursing Department

e-posta: aylin.sayilan@klu.edu.tr

\begin{abstract}
Pressure (decubitus) ulcers are injuries to skin and underlying tissue resulting from prolonged pressure on the skin and one of the negative conditions that disrupt the quality of life of the person. Ulcers most often develop on skin that covers bony areas of the body. Diagnosis and prevention of pressure ulcers as risk factors immobility, lack of sensory perception, poor nutrition and hydration, medical conditions affecting blood flow is very important.

Nurses must to be sensitive about skin care, nutrition, position changing, training and maintain the care with evidence-based about pressure ulcers. This review contains information on causes, risk factors and prevention of pressure ulcers.
\end{abstract}

Keywords: Prevention, Pressure, Ulcer

\section{INTRODUCTION}

Pressure ulcer is a major health problem worldwide (1). According to the National Pressure Counseling Panel (2), it is defined as a localized wound on the skin and / or underlying tissue on a bone spur as a result of pressure or shear. Warning signs of pressure ulcers are: unusual changes in skin color or texture, swelling, pus-like draining, tender areas (1).

Pressure ulcers or pressure sores are a condition that reduces the quality of life of patients and increases the length of hospital stay and the cost of health care. The prognosis of its with infection and complications leads to an increase in mortality (3).

Nowadays, knowledge management, changing health care preferences of the society and cost-effective care policies have made evidence-based practices compulsory (4). The role of evidence-based initiatives is important in the prevention of pressure ulcers. Risk assessment, skin care, nutrition, position changing, education are in the content of 
essential practices, these applications comprise the basis of nursing care.

Pressure ulcers have high cost and mortality. It is a very big problem lots of country. It has become increasingly important in the years, because it shows quality indicators for hospitals (5). For this purpose, lots of health professionals working hard for prevent for pressure ulcer all over the world. But prevention standarts change from institution to institution.

Pressure ulcers can develop quickly. Most sores heal with treatment, but some never heal completely. Nurse can take steps to help prevent it (1).

There are few articles in the literature about pressure ulcers $(3,4)$. The purpose of this article is to share evidencebased practice for prevention of pressure ulcers, power of based evidence and effects of this practice.

\section{Etiology of Pressure Ulcers}

Pressure is the most important factor in the etiology of the pressure ulcers. The factors such as the degree of pressure and the duration of pressure, the resistance of the tissue, the presence of friction and tear, advanced age, nutritional deficiency, the presence of chronic illness, humidity, smoking/alcohol consumption, stress are among the factors causing pressure ulcers (1). Three primary contributing factors for ulcers are: a) Pressure b) Friction c) Shear

\section{Stages of Pressure Ulcers}

\section{International NPUAP-EPUAP Pressure Ulcers Classification System}

Stage I: Persistent skin redness in the place that is pressured by a finger. The pain may accompany it, it may be hard, soft, cold or hot in respect to the area in good condition.

Stage II: There is a partial dermis loss in terms of thickness. Strong clear or strong dark serum may be seen.

Stage III: There is a full tissue loss in terms of thickness. Subcutaneous fat tissue may be seen but bones, tendons or muscles are not affected.

Stage IV: At this stage, there is a full tissue loss in terms of thickness, bones, tendons or muscles are also affected $(3,6)$.

\section{Prevention of Pressure Ulcers}

Risk Assessment: A reliable and effective first step in the planning of the prevention of pressure ulcers is to use risk identification scales to determine the risk of pressure ulcer for individuals. Risk factors include: Immobility, lack of sensory perception (Spinal cord injuries, neurological disorders etc.), poor nutrition and hydration, medical conditions affecting blood flow (such as diabetes and vascular disease).

The most commonly used scales are:

- Braden Risk Assessment Scale: General

- Norton Risk Assessment Scale: Aged population / General

- Bates-Jensen Wound Assessment Tool (BWAT): General

- Waterlow Risk Assessment Scale: Orthopedics / General

- Buçh Pediatrics Pressure Ulcer Risk Identification Tool: Pediatrics

- Suriadi and Sanada Pressure Ulcer Risk Assessment Scale: Intensive care (7).

Using risk assessment tools in daily care by nurses is important to be able to make objective evaluations. Risk assessment tools should be frequently used to provide effective nursing care in the prevention of pressure ulcers. Especially selection of a valid risk assessment tool that is appropriate for the patient population is important.

Skin Care: The first thing to do when encountering a pressure ulcer is to assess the wound. It is essential that the skin is clean and dry. The sites of body that are moistened by sweat and body fluids and the sites of body with wrinkles should be washed with mild soap or pH 5.5 cleansers and rinsed with warm water. Then topical wound care should be provided. The purpose of topical wound care is to keep the wound moist, to mechanically remove debris from the wound and to downgrade the local infection by bactericidal action. Bactericidal solutions such as povidone-iodine, hydrogen peroxide, acetic acid and sodium hypochloride (Dakin solution) and silver sulfadiazine are among the solutions used for medical dressing. Although physiological saline solution does not have bactericidal effect, it is the best solution that can be preferred because it does not lead to tissue toxicity, it also creates a physiological environment to maintain the normal wound healing process. For the effectiveness of medical dressing, gauze patches should 
cover the entire cavity, they should be replaced every $6-8$ hours (8).

Nutrition: Pressure ulcers reduce the quality of life of an individual, cause rapid mortality in some patients and an important cost for healthcare organizations. Therefore, the prevention and management of pressure ulcers are very important. Inadequate nutrition and unbalanced nutrition are the main risk factors for the development of pressure ulcers and wound healing due to their negative effects on the immune system and collagen synthesis. Laboratory tests such as serum albumin, prealbumin, transferrin and retinol binding protein measurements and other anthropometric measurements such as height, weight and body mass index measurements are useful only in the determination of the overall prognosis, but they can not fully identifying the nutritional status of the individual.

Although the effect of optimum nutrient intake is not known in the promotion of wound healing, the positive effects of energy, protein, zinc and vitamins A, C and E, as well as amino acids such as arginine and glutamine are emphasized. Hydration plays a vital role in the preservation and repair of skin integrity. Adequate fluid intake is of great importance to support blood flow to injured tissues and to prevent further deterioration of the skin (9).

Position Changing: Position changing should be adjusted depending on the body region where the ulcer is developed. The patient should be positioned to prevent the contact of the ulcer area to the surface of the bed. If there is no negative situation, the head is kept at $30^{\circ}$; it is recommended to give an angle of $30-40^{\circ}$ to the head in side lying position. The importance of the use of seat squab in stage I and stage II pressure ulcers, avoidance from seating for longer than 1 hour in the patients having a pressure ulcer on sacrum/coccyx or ischia, the use of special tools if it is necessary (especially for heels), slow and forethoughtfully positioning of patients to allow the stabilisation of their hemodynamics and oxygenation, has been emphasized $(10,11)$.

Training: The training of health care professionals is considered as an integral part of the prevention of pressure ulcers. The aim of the training is to reduce the frequency of pressure ulcers by changing behaviour pattern. In the studies, it has emphasized that providing training in different formats such as didactic and video-based education in the classroom environment increases the knowledge level of health professionals on the prevention of pressure ulcers $(12,13)$.
CONCLUSION: In the prevention of pressure ulcer formation, it is very important that the patient's risk situation is assessed and the appropriate scale used. In accordance with the results of the assessment, providing skin care, positioning, ensuring and maintaining nutrition and training of healthcare professionals are key points.

\section{REFERENCES}

1. Wurzer P, Winter R, Stemmer SO, Ivancic J, Lebo PB, Hundeshagen G, Cambiaso-Daniel J, Quehenberger F, Kamolz LP, Lumenta DB. Risk factors for recurrence of pressure ulcers after defect reconstruction. Wound Repair Regen. 2018; 26: 64-68. doi: 10.1111/wrr.12613.

2. National Pressure Ulcer Advisory Panel (NPUAP). NEW 2014 prevention and treatment of pressure ulcers: clinical practice guideline. Availbale from http://www.npuap.org/ resources/educationaland-clinical-resources/prevention-andtreatment-of-pressure-ulcers-clinical-practice-guideline. Accessed at 12. 06.2018.

3. Orhan B. Practice for Preventing Pressure Ulcers: Evidence Based Practices. Archives Med Rev J. 2017; 26: 427-440 doi:10.17827/aktd.306004.

4. Gunes U. Steps of Evidence - Based Practice Process in Nursing. International Refereed J Nurs Res. 2017; 9: 171187. doi: 10.17371/UHD2017.1.0006

5. Serraes B, van Leen M, Schols J, Van Hecke A, Verhaeghe S, Beeckman D. Prevention of pressure ulcers with a static air support surface: A systematic review. Int Wound J. 2018; 15 : 333-343. doi: 10.1111/iwj.12870.

6. Coleman S, Nelson EA, Keen J, Wilson L, McGinnis E, Dealey C, Stubbs N, Muir D, Farrin A, Dowding D, Schols JM, Cuddigan J, Berlowitz D, Jude E, Vowden P, Bader DL, Gefen A, Oomens CW, Schoonhoven L, Nixon J. Developing a pressure ulcer risk factor minimum data set and risk assessment framework. J Adv Nurs. 2014; 70: 2339-52.

7. Firat Kilic H, Sucudag G. The Scales Frequently Used in the Assessment of Pressure Sores. G.O.P. Taksim E.A.H. JAREN. 2017; 3: 49-54.

8. Beğer T. Pressure Sores in Intensive Care: Risk Factors and Prevention, 2004; http://www.yogunbakimdergisi.org/ managete/fu_folder/2004-04/html/2004-4-4-244-253.html.

9. Saghaleini SH, Dehghan K, Shadvar K, Sanaie $\mathrm{S}$, Mahmoodpoor A, Ostadi Z. Pressure Ulcer and Nutrition. Indian J Crit Care Med. 2018; 22: 283-289. doi: 10.4103/ ijccm.IJCCM_277_17.

10. Peterson MJ, Gravenstein N, Schwab WK, van Oostrom JH, Caruso LJ. Patient repositioning and pressure ulcer risk-monitoring interface pressures of at-risk patients. J Rehabil Res Dev. 2013; 50: 477-88.

11. Behrendt R, Ghaznavi AM, Mahan M, Craft S, Siddiqui A. Continuous bedside pressure mapping and rates of hospitalassociated pressure ulcers in a medical intensive care unit. Am J Crit Care. 2014; 23: 127-33. doi: 10.4037/ajcc2014192. 
12. Porter-Armstrong AP, Moore ZE, Bradbury I, McDonough S. Education of healthcare professionals for preventing pressure ulcers. Cochrane Database Syst Rev. 2018; 5: CD011620. doi: 10.1002/14651858.CD011620.pub2.
13. Ham WH, Schoonhoven L, Schuurmans MJ, Veugelers R, Leenen LP. Pressure ulcer education improves interrater reliability, identification, and classification skills by emergency nurses and physicians. J Emerg Nurs. 2015; 41: 43-51. doi: 10.1016/j.jen.2014.03.005. 